\title{
"Profit": A new key concept in Russia and the Czech Republic. Parallels and differences"
}

\author{
Johanna Petters, Barbara Müller ${ }^{* *}$
}

The article describes how the concepts - i.e. people's knowledge and attitudeconnected to the Russian and Czech words for profit have changed during the transformation after 1989. In the socialist period capitalist profit maximization is stereotypically damned whereas socialist profit remains rather an internal matter of the enterprises. In the 1990ies both the profits of particular enterprises and the general notion of profit become a public matter. In specialized and newspaper texts profit is endorsed as a motivation for people to work and the driving economic force. In Czech spoken discourse people are often skeptical towards the notion of profit.

Der Artikel beschreibt, wie sich nach der "Wende" von 1989 die Konzepte - d.h. Wissen und Einstellungen - zum russischen bzw. tschechischen Wort für Gewinn verändert haben. In den Texten aus sozialistischer Zeit wird kapitalistischer Gewinn stereotyp verurteilt. Sozialistischer Gewinn ist meistens eine interne Angelegenheit der Betriebe und nur eine von mehreren Kennziffern. In den 1990ern wird Gewinn zu einer Sache, die alle angeht: Er wird als wichtigstes Betriebsergebnis veröffentlicht; der Begriff wird eingehend diskutiert. In Fachund Zeitungstexten wird er als Arbeitsmotivation und treibende wirtschaftliche Kraft positiv bewertet. Im tschechischen Alltagsdiskurs herrscht eine skeptische Einstellung gegenüber Gewinn bzw. Gewinnstreben vor.

Key Words: Profit / Economic transformation / Corpus linguistics / Key words concept

\footnotetext{
* Manuscript received: 31.07.03, revised: 28.01.04, accepted: 10.02.04

**Johanna Petters, born 1971, Research Assistant Vienna University of Economics and Business Administration Department of Slavic Languages (2002/2003). Main research topics: Corpus analysis, Myths of the Soviet Union. Corresponding address: johanna.petters@gmx.at

Barbara Müller, born 1970, Research Assistant Vienna University of Economics and Business Administration Department of Slavic Languages (2002/2003). Main research topics: discourses analysis, languages of minorities, Market discourses. Corresponding address: barbara.mueller@utanet.at
} 


\section{Introduction ${ }^{1}$}

The aim of this paper is to describe "profit" (Russian pribyl", Czech zisk) as a keyword of the market economy in current Russian and Czech. Central to our analysis are the changes in the concept of this word that occurred in the wake of the political and economic upheavals in Central and Eastern Europe around 1990. Our hypothesis is that even if the basic definition of a word (i.e. its meaning) remains unchanged, societal changes can affect the concept of this word, i.e. people's knowledge, values and attitudes connected to it. A concept, being a unit of the mental representation of our real-world knowledge, can only be identified indirectly, e.g. by the word that is tied to it. We therefore study the actual language use in connection with the keyword in question in order to find out about the structure and development of the attached concept, or rather its socially shared aspects.

The following paper starts from a short description of the analysed material and the applied method. After that we will present the meaning and use of the Russian and Czech equivalents of profit $^{2}$, especially concentrating on the shifts in the related concepts. Correspondingly, the main part of the paper is structured in chronological order, starting from Czech usage in the 1970s, going on to the Russian language of the Perestroyka period and then covering in detail the 1990s both in Russian and in Czech. We will show how, as a result of social and political change, the concept of the economic term profit has developed and eventually converged with the corresponding concept in a market economy context.

\section{Method of analysis}

The main method applied in the study is the quantitative and qualitative analysis of electronic text corpora - large collections of texts that have been compiled in order to reflect the language use of certain periods and domains. In order to examine the use of the Czech language before and after the fall of the iron curtain we use one corpus from the 1970s and several from the 1990s. The language use of the socialist period is represented in the so called "Marked corpus of Czech texts from the years 1972 to 1975 " which was kindly provided to us by the Institute of Czech language at the Academy of Science of the Czech

\footnotetext{
${ }^{1}$ This paper presents results of the research project "Market Discourse as an Indicator of Globalisation and Transformation" at the Department of Slavic Languages at Vienna University of Economics and Business Administration. The project is sponsored by the Anniversary Fund of the Österreichische Nationalbank (project number 9166) and supervised by Renate Rathmayr, head of the Department of Slavic Languages.

${ }^{2}$ We ignore synonyms of Russian pribyl and Czech zisk such as the foreign word profit because of their low frequency. Derivations like e.g. Czech ziskový are also left aside in this article due to lack of space.
} 
Republic. It contains 540000 words of non-fictional text material: mainly professional and scientific literature from various fields, but also administrative and media texts. $25 \%$ of the texts are transcripts of spoken language such as lectures, radio programmes or professional meetings.

For the 1990s we use the Czech National Corpus, which was compiled at the Charles University in Prague and can be accessed via the Internet ${ }^{3}$. It is made up by several separate corpora by far the largest of which is the so-called Syn 2000. This corpus of written language has more than 120 million words and contains mainly newspaper texts, although it also provides other, different genres (such as novels, science books and songs).

We also worked with two corpora of spoken language that are provided by the Czech National Corpus: the Prague Spoken Corpus, containing 49000 words and consisting mainly of transcripts of interviews on everyday topics from the years 1988 to 1996; and the Brno Spoken Corpus, containing a little less than 40000 words of spoken language from the Morava region recorded between 1994 and 1999.

Additionally, we examined two corpora of spoken language compiled by the Czech linguists Olga Müllerová and Jana Hofmannová. The "Spoken Czech in Authentic Texts" corpus $^{4}$ is a representative sample of characteristic communicative situations from the years 1990 to 1992. The second corpus, called Research (Výzkum), contains interviews recorded in 1994 and 1995 on the topic of quality of life.

As for Russian we have access to three different text corpora from different periods: The so-called Uppsala-Corpus consists of 1 million words of written prose, one half of which is fiction published between the beginning of the $60 \mathrm{~s}$ and the late 1980s, while the second half is from newspapers and magazines from the years of 1987 and 1988. It thus reflects very well the Russian language of the Perestroyka period, when new views on economics and business were however carefully - being introduced. A second corpus of about 151000 words are the transcriptions of 16 extensive interviews conducted by Russian sociologists with families at St. Petersburg in 1993 about their social situation ("Pietar-Corpus"). These interviews were designed at the University of Tampere/Finland for a study on survival strategies in post-communist Russia and provided to us for linguistic analysis by Maria Leinonen. This corpus, unlike the two others, represents spontaneous oral speech. The third Russian language corpus is a compilation of the issues 20/1996 to 37/2000 of the popular Russian weekly "Ogonyok", with approximately 5,8 million words. The

\footnotetext{
${ }^{3}$ http://ucnk.ff.cuni.cz

${ }^{4}$ Mluvená čeština v autentických textech
} 
Uppsala and Ogonyok corpora are both maintained at the Slav Department of Tübingen University and accessible via the Internet ${ }^{5}$.

We have thus at our disposal linguistic data from before and after the reforms and data that represents the transition period around 1990. The differences between the corpora concerning size, content, genres, spoken versus written texts etc. must of course be taken into account in their comparative analysis. Qualitative analysis prevails with the smaller corpora of up to one million words, while mainly quantitative methods are applied to the larger ones.

\section{Profit in Czech and Russian dictionaries}

The Russian equivalent of the word profit is pribyl', in Czech it is zisk. In neither Russian nor Czech are these in any way new or newly borrowed words. They can be found in encyclopaedias from before 1900 (Brokgauz/Efron 1890) as well as in the works of $19^{\text {th }}$ century authors, e.g. Leskov and Gogol' and their meaning has not changed since then. Present-day dictionaries define the word as "the sum by which the income exceeds the costs" or very similarly (cf. Ožegov 1993; Skljarevskaja 1998). Two additional meanings of Russian pribyl are "use, advantage, benefit" in colloquial speech and "rise, increase (of water, inhabitants etc.)." Interestingly, these do not occur in the analysed material at all, which leads to the conclusion that the financial meaning of the word clearly predominates in standard written and spoken Russian.

In Czech encyclopaedias we find explanations of zisk that are very similar to the Russian understanding of profit. Encyclopaedias usually refer only to the economic meaning of the word. However, the word zisk has a broader meaning as we can clearly see when we look into the dictionaries. It is closely related to the verb ziskat (to acquire/to gain) and can thus refer to practically everything that can be acquired or gained. Although in the vast majority of our examples it is used in its economic sense we could also find examples where it denotes the acquisition of other things such as votes, territory or trophies and points in sports competitions. Sometimes it is also used for non-material profit. Thus, the Czech word zisk has a semantic range that is very similar to the German word Gewinn.

Czech and Russian encyclopaedias and dictionaries from the period of socialist planned economy define the word in the same manner as today, however, additionally they all consistently distinguish very strictly between profit in capitalist systems and profit in socialist systems. According to them profit in capitalism is made basically by the exploitation of workers and by excessive prices, while in socialist societies it is reached through the increase of productivity and of quality and the minimisation of production costs. Profit in

${ }^{5}$ http://www.sfb441.uni-tuebingen.de/b1/korpora.html 
capitalism is only made by a few individuals, in socialism all members of the society benefit from it. The concept of capitalists' profit represented in these works of reference is rather vague and negative, while the means and processes that lead to the "socialist" profit are described in a detailed and more factual way. In reality, these means and processes do not differ from the ones applied by businesses in a capitalist society, on the one hand, and they cannot automatically exclude the exploitation of employees, on the other hand. In the official view of socialist economic sciences, though, the equation of both concepts was incorrect and revealed the "anti-scientific views" of Western economists, as the Great Soviet Encyclopaedia (vol. 20, 1975) puts it. Apparently, the capitalist connotation of profit was so strong that this differentiation had to be applied to legitimate the use of the word in the context of a socialist economy.

The described division between a capitalist and a socialist concept of profit might seem rather artificial at first sight. But the examination of language use in the time before transformation indeed hints to the establishment of two distinct concepts in Czech and in Russian, as will be shown in the following chapter.

\section{Profit in Czech language use before Transformation}

Most of the 33 examples of zisk (profit) that we find in the Czech "Marked Corpus of 1972-1975" can be clearly attributed to one of the two concepts mentioned above - either pertaining to a socialist, or to a capitalist economic system:

Profit in capitalism: Eight examples in four texts show the socialist concept of capitalist profit. Most of these texts argue that similar phenomena have different consequences in capitalist and socialist society due to the inherent dynamics of the respective social system. Phenomena like management - or regulation as it was called in socialist countries - or the so called scientific-technical revolution do great benefit for socialist society whereas they widen the gap between the classes and worsen the situation in capitalist societies.

The contents of capitalist management are determined mainly by the relations of production just like the contents of socialist regulation. Thus the fundamental economic law of capitalism - the striving for maximum profits, which finally determines the essence, the forms and the style of management in capitalism is the basis of management theories, just as regulation in socialism is the realisation of socialist distribution of property and a function of socialist state power. (Czech 72-75)

Not only in this example is profit maximisation described as the driving force of capitalism. The striving for maximum profit as the main characteristic of the capitalist society is repeated stereotypically when it comes to confronting the benefits of the socialist system to the inner contradictions of the capitalist 
system. We never learn how much profit is made and in what way, nor do we get any information about the entrepreneurs who make this maximum profit. They remain as vague as the concept of profit itself. What we learn is that they are only a small group that lives and prospers by exploiting the masses of working class people.

The scientific-technical revolution also has different consequences. In socialism it contributes to the acceleration of social development, whereas in capitalism it activates all the oppositions and contradictions of capitalism. In capitalism, its benefits are used for further exploitation, for imperialist deprivation of the people, for the raising of profits. (Czech 72-75)

Profit in socialism: The socialist concept of zisk (profit) is less vague. The examples we find here mainly inform us about economic results of certain enterprises. The word also occurs in a collective contract where the relation between the profit of the enterprise and the wages of the workers is defined. Unlike in the texts about capitalism here we learn who made a profit and how much profit was made:

In the past year the workers of our national enterprise were successful in fulfilling all decisive directives of the plan. The hitherto highest profit was made, that is $[\ldots]^{6}$, and the workers also achieved significantly in lowering the costs of material by [...] compared to the figures of the year [...]. (Czech 72-75)

Here the workers make the profit, not the entrepreneurs. It is a representative of the company who informs the public: workers of our national enterprise. This is typical for the 1970s. Similar examples we find in this corpus are from an article in an enterprise's internal magazine, an interview with the director of the municipal people's committee (about the profit of the municipal services) and the minutes of a meeting of a collective farm. Therefore, it is always somebody closely related to an enterprise who talks about its economic results. Profit remains an internal affair and is publicised only when the results are positive. The only case where we find negative results are minutes which were written only for internal use.

Profit is not the driving force, but only one of the indicators of economic results, one of the aims that have to be reached according to the five-year plan. As the plan prescribes concrete figures the aim is not maximisation but reaching these figures. A second indicator that is at least as important as profit is the production (výroba) or production capacity (výkon) of the enterprise, which is also expressed, in concrete figures. In most of our examples this figure comes before profit as is the case in the following example.

${ }^{6}$ In the "Marked corpus of Czech texts from the years 1972 to 1975 " numbers are omitted. 
At today's conference on technical and economic affairs the participants were informed about the specified directives of the enterprise's plan for the current year, which are again more ambitious and account for a rise of production by $[\ldots]$ and a rise of profit by [...] compared to the figures that were reached last year. (Czech 72-75)

\section{Excursus: Capitalist theories in the 1970s}

In one text of the 1970s corpus we find eight uses of zisk that do not fit into either of the two concepts represented in the dictionaries and encyclopaedias. In this geography lecture, which was probably not designed for a wider audience, the lecturer refers to the theories of the German economists Johann Heinrich von Thünen and August Lösch. These theories came up in the $19^{\text {th }}$, respectively in the first half of the $20^{\text {th }}$ Century, and are clearly closer to capitalist views than to socialism. Nevertheless, the lecturer refers to them without criticising them from the socialist point of view. He finds nothing extraordinary in equating the sense for profit with the sense for economic action.

The fourth condition [for the functioning of von Thünen's theory] is [...], that the farmers who deliver the agricultural products to the market all have an equally developed sense for business, that is an equal sense for profit. (Czech 72-75)

In addition, the assumption that a cheaper work force brings higher profit as we find in the following example rather indicates a capitalist notion of profit.

This localisation factor is defined as the advantage that a given production gets from settling at a certain location. The advantage can be cost savings; furthermore, it can be advantages on the grounds of higher profit due to a cheaper work force. (Czech 72-75)

It seems that - during the 40 years of socialist regime in Czechoslovakia - the socialist dual concept could enter into the official discourse as represented in dictionaries and newspapers, but in the less official layers of discourse a market economy notion of profit did not vanish completely. Nevertheless, in everyday public and in economic discourse the official concept applied, which also meant that overall profit was a significantly less important concept for economic activities than in market economy societies.

\section{Profit in the Russian language of the Perestroyka period}

The word pribyl' (profit) occurs 47 times in the Russian language 'UppsalaCorpus" from the end of the 1980s, always in newspaper and magazine articles and never in literary texts. The word appears partly in contexts that are typical of the previously depicted concept of "profit in socialism." For example, the second frequent topic of texts containing the word pribyl' is the description of 
technological innovations. As was already mentioned making profit by technical progress is a traditional aspect of the official socialist concept, and therefore an inoffensive context for the use of the word. In addition, profit is in some cases still conceptualised as one factor among others, with the production output - i.e. the supply of the population with consumer goods - being more prominent than the profit.

Many other uses of pribyl ' (profit), however, hint to a new treatment of the word in the media of that period. Thus, the topic with the highest frequency is economic reform. 23 texts in the Uppsala corpus contain the word pribyl', 15 of them criticise the economic situation of the time or deal with economic reforms. The tendency of this discourse is to ascribe a higher importance to profit than it had had in the official view of the Soviet authorities before the beginning of Perestroyka reforms. Confer, as an example of criticism, a very open description of the difficulties of collective farms that are caused by the shortage of building materials and certain rules that limit the purchase of such materials. Here, profit is already seen as a very important prerequisite for economic activities, and the author complains that the economic system to which the state adheres inhibits its positive effects:

It seems that the dump has become almost the only place where kolkhozes and sovkhozes nowadays quite uninhibitedly supply themselves. It is not just some bankrupts [...] that mine them, but suppliers from farms with a profit of millions in their accounts. (Izvestija 1987)

In many cases, planned or already implemented reforms are discussed, as is the case in the following section of text. It describes newly introduced "innovation banks" which give loans to enterprises. First, the principles of their work are explained - with profit as the central motivating factor -, then an example of an already existing and successfully working bank is given:

Innovation - that is what the activities of these banks are all about. Funding, loans for the costs of [...] innovations - from the idea to implementation, with a share in the profits later, which motivates the banker's genuine concern for the effectiveness of the loan. This effectiveness is expressed, among other things, by bonus payments to the bank employees. The first innovation bank has just started work in Leningrad. It has turned out to be a lucrative thing. (Izvestija 1988)

Criticism of a condition and the presentation of a reform solution are often connected in one article. Central to this discourse of economic reforms is the question which role profit plays in economics and business administration and that its role must be increased:

[...] the independence of workers' collectives, as intended by the law on stateowned enterprises in such matters as planning or the distribution of part of the 
profit, in reality collided with attempts from above to rigidly plan production targets as well as to decide on the profit of enterprises. (Izvestija 1988)

An article on the reorganisation of state enterprises explains what the newly introduced principles "full economic accountancy" (ru. polnyj chozrasčet) and "self-financing" (ru. samofinansirovanie) mean. Here the whole concept of leading a company is already built around the goal of making profit:

All the activities of the enterprise [...] are carried out with the money earned by the workers' collective. [...] The indicator of economic activities is the profit. The higher the profit the more lucrative the enterprise. The higher the productivity of labour and the quality of the products, the lower the expenses, the higher the income, and with a bigger income, the enterprise has more possibilities [...]. (Technika i nauka 5, 1988)

Another typical feature of the analysed texts of the Perestroyka period is also illustrated by the above example: Many articles explain in a detailed, yet comprehensible way how certain economic mechanisms work. This shows that the ideas introduced are indeed new to the readers. In one case, a report about the direct cooperation between two kolkhozes, without the usual mediation of a ministry, uses the words "customer" (zakazčik) and "contractor" (ispolnitel) in quotes to refer to the two kolkhozes. This shows just how new ideas like direct business contacts between two enterprises, without the mediation and control by official authorities, were at that time.

The implementation of the Perestroyka reforms, and associated ideas and principles, was not a grassroots movement. It was masterminded and directed from above. This seems to be another reason why innovations are described very carefully: They have to be legitimated with the people, the readers, because they often contradict the ideology advocated and enforced by the Soviet state in the decades before. This becomes especially noticeable in articles that deal with a new legislation, e.g. the "Law on state enterprises", related to in the above examples, or the legalisation of so-called individual (i.e. private or freelance) work. The typical structure of such a text is to admit that the reform in question is indeed unusual and difficult to understand, and then to explain its meaning and its importance for the country's further economic development.

The state controls not only the reforms; it also wishes to keep control over the profits that the individual enterprises make. This remains quite obvious in spite of the increased importance ascribed to the concept profit for a better functioning economy with greater independence for each enterprise. When the Soviet minister of finance in an interview on budget affairs mentions that the state's income recently decreased, because "70 percent of the drawn profit that exceeds the five year plan started to remain at the disposal of the enterprises" this shows how limited the enterprises" access to their own profit actually was. Confer also the statement "This year [...] "Shveitekstil 'trikotazh" will give the 
state a profit of about 45 million," this being a justification of the existence of an enterprise that employs handicapped persons. So, profit is still made predominantly for the benefit of the state or the society, rather than for an enterprise, or even an individual. The Soviet authorities of that time tried to implement profit as a motivation for better performance, while still clinging to many principles of a centrally planned economy.

A very new phraseology introduced by Perestroyka discourse is the possibility to take the "West" as a model for reforms - unlike earlier, when comparison was allowed only to show the advantages of the socialist system. Now there are cases where the criticism of the own system is spelled out very directly, and even sarcastically:

It seemed that everything was wonderful. We at last succeeded at least somewhere in overtaking the leading capitalist countries. However, it appears, not that we overtook them, but they wanted to stay behind. In the USA and Japan, they simply studied the demand for robots first, determined where they could be profitable and only then started production. (Technika i nauka 2, 1988)

It will be shown later that this emulation of the West becomes even stronger in the 1990s.

To conclude this chapter it can be said that in the Russian sources from the Perestroyka period of the late 1980s tendencies toward a conceptual shift of pribyl' (profit) are clearly visible. The importance of profit in economic activities is increased and its meaning is discussed intensively. The traditional antagonism of a negatively evaluated Western and a positively evaluated Eastern variant is at the same time attenuated.

\section{Profit in Czech after the end of centrally planned economy}

In the Syn 2000 Corpus, the corpus of written Czech language of the 1990s, we can clearly see how zisk (profit) has become a central concept both in economic theories and in accounting.

According to the market economy theories that are now being implemented and discussed, zisk (profit) is seen as the driving force of economic action. This notion, however, had already been present in the socialist concept of capitalist profit. Now this vague and at the same time unambiguous idea of profit is integrated with other aspects, that before the introduction of market economy were part of the socialist concept.

Although profit maximisation is now accepted as the major objective of any business there are also other objectives that have to be considered - sometimes even at the expense of a higher profit - as in the following passage from a marketing textbook. 
Fig. 1. The significantly higher frequency of the word both in Russian and in two languages.
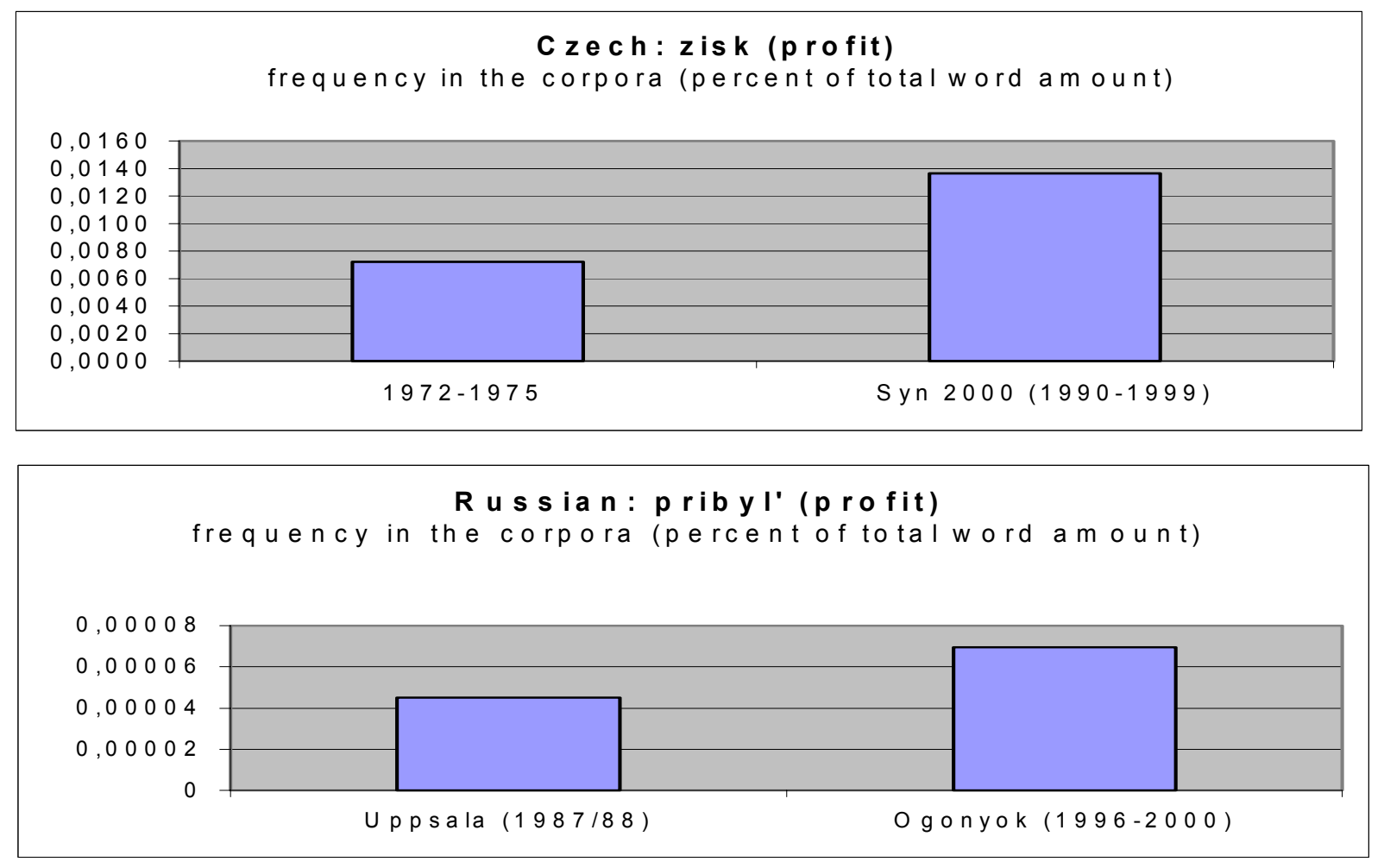

The objectives of marketing must be a consequence of the enterprise's objectives. Among the objectives that are usually observed are above all:

- profit maximisation, which can mean maximisation of long term profit or the maximisation of the current profit, e.g. in a quarter or a year, which is more common, as the profit can be set down and controlled more easily in a shorter period of time.

- keeping or raising the turnovers, an objective that is usually observed if the profit is acceptable and a higher sales volume leads to lower unit costs.

- $[\ldots]$

- social responsibility, if the enterprise renounces higher profits in reaction to pressure from the environment and rather follows the interests of the society (Stehlík: Základy marketingu. 1999).

What we can also see from the above passage is that profit maximisation is no longer a stereotypical formula but can be differentiated according to the concrete objectives of the enterprise. This is only one of many examples where the capitalist concept of profit becomes more complex from an inside point of view. 
After the Marxist theory lost its function of being the one and only axiomatic truth, different economic theories are being introduced and discussed bringing about many different notions of profit.

In the course of the 1990s, the notion that profit must not always be the major goal gains ground. Like in many western countries, the question of where profit orientation fosters economic development and where it harms the social balance starts playing an important role in the discourse. It is also reflected in a treaty that was signed in 1998 by the governing Czech Social Democratic Party and Democratic People's party supporting the socialist minority government.

A topic of permanent debate between left and right governments is the discussion about the desirable share of public and private sector. The government disclaims ideological fundamentalism, which in its communist emanation lead to the elimination of the private sector. The government does not share the ultraliberal views on cutting back the public sector, either. It endorses the attitude of the European Union on a continuous partnership between the two sectors and is conscious of the fact that in practical politics the frail and from time to time changing balance between the two has to be looked for anew again and again. We do not think it advisable for economic subjects whose task is profit maximisation to remain in the hands of the state, but we do not think that the providers of public services should be unrestrictedly subjected to the invisible hand of the market either. The government holds the opinion that the market mechanism is useful mainly in the case of short-term allocation of resources. Those fields with a long time passing between the investment and its results - as e.g. education or pure research - the government thinks should be part of the public sector. (Politika v ČR 1998. Brno 1998)

Profit maximisation is no longer seen as characteristic for a social system as it was before the Transformation, but is now rather associated to private enterprise. Thus, privatisation becomes another important aspect of the concept of the Czech word zisk (profit). On the practical microeconomic level profit is no longer one factor among others to be fulfilled according to the five-year plan. It is now the major figure informing a broad public about the success or failure of an enterprise.

The majority of hits for zisk (profit) in newspaper texts from the 1990s are articles which inform the readers about how much profit an enterprise has made in the past year or how much it is going to make in the near future. Here is just one example:

Czech savings bank doubled profit in the past year PRAGUE ( jaš ) - The Czech savings bank closed last year's annual accounts with a profit of 980 million crowns. Compared to 1993 this amounts to a growth of 661 million crowns. On the basis of these results the board of directors will propose to pay a dividend of 7 crowns for each hundred crowns share at the shareholders' 
meeting. In the past year 5 crowns were paid. The Chief Executive Officer of the Czech savings bank Jaroslav Klapal informed journalists about this yesterday. The amount of profit was influenced by the need to create high reserves that would correspond with international banking standards. J. Klapal further stated that the increase of the obligatory minimal reserves from 9 to 12 percent also had a negative influence on the amount of the profit. (Hospodářské noviny 1995)

The whole article is only twice as long as the passage quoted here and as we can already see from the title, its main topic is the profit of the Czech savings bank. Whereas in the corpus of the 1970s we found no texts with profit as their central topic, such texts occur quite frequently in the 1990s. Especially the frequent use of zisk (profit) in captions indicates to the fact that profit has become a key concept of the period.

As everybody has now the right to buy shares of a public company, the profit of most companies is no longer an internal matter, but has to be made accessible to the public via the press. The share holder's interest in the profit is the reason why many articles on the topic of profit inform not only about how much profit was made but also about what is now going to happen with the money and what factors were responsible for realising this concrete sum of money.

As we can see from an article commenting on the adaptation of the accounting system to the standards of the European Union this publicity of economic results was really something new.

During the transition period before the beginning of the big privatisation, one could hear the opinion, among others, that there is no need for a denationalised enterprise to announce the results of its economic activities anywhere or to anybody. When a list of 1490 Czechoslovakian enterprises with the most important figures was published at the beginning of the first wave of the voucher privatisation in 1992, the specialists' community took this as the breakthrough of the economic information barrier. The matter was clarified completely with the Ministry of Finance's implementing regulations for the accounting act. They strictly oblige medium and large concerns to publish a minimum extent of the most important figures of their annual accounts attested by an auditor. Maybe it came as a surprise to some people that the enterprise cannot regard these figures as its secret. This is also not possible in the civilised world of developed market economies. In our neighbouring EU-countries the figures for property and annual accounts of the big capital companies' economic activities fill whole pages of the public gazettes. We will have to get used to the fact that the publication of figures in the Obchodní věstník [newspaper "Trade Bulletin”] is part of the new system. (Hospodářské noviny 1995)

In the same article, the author criticises that the new methods of accounting do not show any figure comparable to výroba (production output) - one of the most 
important indicators of economic results in the communist period. For him the fact that in the new system the major indicators are turnover and profit and that there is no figure which would characterise the volume of the main activities of the enterprise indicates that in the basic philosophy of modern entrepreneurship the main problem is not producing, but selling.

In the new accounting methods the second important figure apart from profit is the turnover (obrat) of an enterprise. It is sometimes mentioned in newspaper information of economic results. Still, profit is clearly dominating.

The adaptation to EU methods brings some confusion into the concept of profit and is accompanied by big discussions. The confusion is especially obvious with the economic term balance profits (bilančni zisk). Whereas in socialist accounting it denoted the gross profit before taxes, it is now rather used for the net profit. The confusion this new meaning can bring about is also commented by the author.

This is not a discussion in a linguistic circle, but it is a matter of different expressions also having different meanings and referring to different values (figures) of the financial data in question. [...] According to the old method balance profit meant the overall annual profit of an enterprise before deduction of all tributes and taxes. [...] The old profit and loss account actually closed with the gross profit and did not contain any data about the net profit after tax. [...] The new profit and loss account closes with the net profit and as this figure is the result of the whole balance of income and cost it can also be regarded as balance profit. (Hospodářské noviny 1995)

The broad discussion that accompanied the implementation of the new concept mirrors in the especially high frequency of the key word zisk (profit) in the period after the introduction of the new method of accounting in 1993 (cf. p. 202). Fig. 2 shows the frequency of cz. zisk as related to the number of the female past tense forms of the verb to be (cz. byla) in percent. This method of counting has to be applied, because there is no information available as to how many words the Syn 2000 corpus comprises for each single year.

Special economic terms that are formed with an adjective plus zisk such as the above mentioned balance profit (bilančni zisk) appear with a strikingly higher frequency in the 1990s. Whereas the only examples for this kind of terminology in the 1970s corpus were two hits of balance profit/bilančni zisk, the most frequent collocates of zisk in the Syn 2000 are čistý (net) and hrubý (gross). This again indicates that the differentiation of different kinds of profit now plays a bigger role.

Although the expressions net profit (čistý zisk) and gross profit (hrubý zisk) have undoubtedly become part of many people's concept of profit this does not automatically mean that everybody knows the exact meaning of these terms. For people who are not economic experts it can even be difficult to distinguish 
between profit/zisk and income/príjem as in the following passage from the Prague spoken corpus.

Fig. 2. Frequency of cz. zisk in the 1990ies

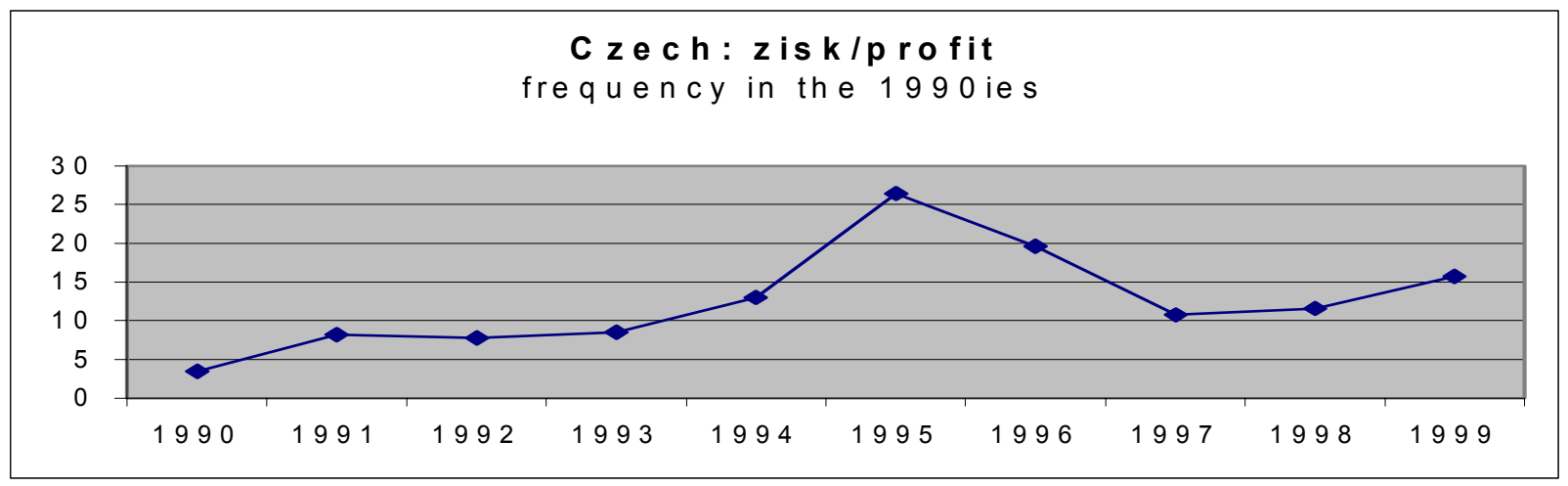

A: And he cou..., he made me a balance-sheet and counted up, that with the rent as it will probably be, as I have heard, well, how high it is going to be and all that, and with all the other, that I will have to earn about thirty five thousand a day.

B: A day?

A: A day!

B: Wait, income or profit?

A: A day...income, no, profit, income [...] (Prague spoken corpus)

There seems to be a big gap between the concept as we find it in the media discourse, where most texts dealing with profit are written by experts, and the discourse of every day spoken language. Here, a critical attitude towards profit prevails. In three of the four examined corpora of spoken language (zisk did not occur in "Spoken Czech in Authentic Texts") we found 9 examples (out of 22) where people express their concerns about the profit orientation they see as dominating in the new market economy society.

I cannot express myself, but the misery of mankind. I ... I am afraid, that, that mankind will die out because they do everything for profit, everything for profit (Brno spoken corpus)

Most of the interviewed people seem to have quite a vague notion of profit and to equate it to market economy in general as in the following passage where the interviewee says what will happen to the Czech cinema when cultural affairs will be handled according to market economy principles.

Our cinematography $[\ldots]$ will be market orientated, it is true and ... well, like, have profit [...] it will be profitable and market orientated, yeah, it'll be flourishing and market orientated, but it will be poor, yeah, and stupid. (Prague spoken corpus) 
There are more examples, in the written as well as in the spoken corpus of the 1990 s, where profit or profit-orientation is conceptualised as something that becomes more at the expense of other values like the protection of the environment, high standards in art or quality of life, or family life:

People very much lack humbleness; they are impatient and want everything immediately. Well ... this running after profit today will become a disaster because children do not know anything of their families except money, they will not know how to ... I don't know ... do you know a family that gathers in the evening and sings something?

In the 1990s, the two formerly distinct concepts of profit are joined into one, the new concept thus becoming more complex. This new concept integrates the negative aspects of profit or profit orientation that were formerly attributed to capitalist profit as well as accepting it as a very important factor of economy, so zisk (profit) is not only the seemingly neutral economic term as which it often appears in newspapers. It is subject to discussion and criticism as becomes especially obvious in every day discourse where it quite often embodies market economy with its negative consequences and conveys projection space for people's fears. In such cases traditional communist notions intertwine with the counter-movement against neoliberalism and globalisation that is currently to be found in most western democracies.

\section{Russian profit in the $1990 \mathrm{~s}$}

There are fewer and smaller corpora for that period in Russian than in Czech, the most important difference, though, being the smaller variety of genres. Therefore conclusions about the use of pribyl' (profit) are limited to the language of the media and to the everyday speech used in the Pietar Interview Corpus of 1993.

The Russian word pribyl' (profit) occurs 8 times in 5 of the 16 analysed sociological interviews. This is very little compared to the 356 occurrences of money, which is the word that people use when they talk about their own, everyday lives. Profit, on the contrary, is reserved for more theoretical reasoning about Russia's economic situation. Wherever it is used a positive attitude to profit in a capitalist context prevails. It is conceptualised as the driving power of economics and the motivation for good work. One interviewee thinks that in the communist system people 'unlearned' how to work properly, because they "did not see the results of their work", meaning financial benefits. He continues:

If somebody works getting a percentage, he starts to understand that the bigger the share in the profits, the deeper his pocket. (Pietar 93) 
A second subject stresses the importance of private property for improvements in the society as a whole. In her opinion financial incentives and profitorientation should also be applied in the public sector:

$[\ldots]$ and there, in the civilised countries even state officials are given quite a significant $m m m$... salary, for example, some ten percent of the profit [...] (Pietar 93)

The ideas about the "West" may still be vague, as the above example illustrates, but profit is central to the conceptualisation of the functioning of economics, and even of the society. None of the examples from this interview corpus reveals a negative attitude towards profit-orientation, except, partly, for one case where the concept of profit is that of a luxury that is very far away from the life of ordinary Russians:

I want to get normal money [i.e. a reasonable salary] for my work, so that I can maintain my family; the rest does not interest me; I do not want to make a profit with it and travel twice to Miami. (Pietar 93)

Profit in these interviews is still, as in the Uppsala corpus, a rather abstract concept applied when people talk about the overall social and economic situation. Only one subject tells about the profit his employer makes. Still, it is now definitely seen as the centre of all economic activities. Thus, the usage in these interviews reflects very clearly the continuation and effect of the Perestroyka discourse, when a new concept of profit was being implemented.

The Russian sources from the second half of the 1990s (the miscellaneous articles from the Ogonyok weekly of 1996 - 2000) prove that in Russia, too, profit has become the centre of entrepreneurial activities and economic thinking. Rathmayr et al. (1999) show, that native speakers of Russian associate mainly positive ideas with the word pribyl' (profit) and see profit as the goal and reward of good work, but it can also be the result of good luck. These findings are supported by the data from the Ogonyok 1996-2000 corpus: An important topic in the Ogonyok texts is the question of how profit is made, or where it comes from. Accordingly, the verbs prinosit' (bring) and davat ' (give) occur especially frequently together with pribyl'. A closer look at sentences with the pattern "X brings profit (to Y)" reveals as sources for profit: concrete products and services ("Roverbuk" notebooks; sausage; the first series [of a film]), companies, persons (such clientele; [Garri] Kasparov; each of us) and more abstract qualities, circumstances, or projects (somebody's publicity; a discovery; the devised construction plan). The most important economic sectors in this context are entertainment and the media, and transport and tourism.

Generally, profit in the Ogonyok articles from between 1996 and 2000 is something much more concrete than in the earlier sources. There are few theoretical discussions now, but reports about companies, business people, activities and the like. 
Among the most frequent verbs that occur together with pribyl' (profit) is polučat ${ }^{\prime}$ ). This verb is often translated with get, receive, but it also means to obtain. In the phrase polučat " pribyl " the appropriate translation is therefore to make profit. Especially German speakers are tempted to interpret this phrase wrongly, as the German equivalent usually given - bekommen - means to receive or to be given. Such an incomplete transfer of the Russian meaning to German may affirm the widespread stereotype about Russians as being passive and dependent, while in fact the present-day Russian concept of making profit is very near to that in German or English.

Several occurrences of pribyl' in horoscopes lead to the conclusion that profit is not only conceptualised as something very positive, but also as partly depending on good luck. Interestingly, making profit by illegal or unethical means is typically connected to the use of a special verb, izvlekat ' (derive). This, however, was found in the analysed corpus only 6 times, as opposed to the 46 records of polučat' pribyl' (make profit).

A look at the adjectives defining pribyl' reveals one dominating semantic group: Of 142 adjectives 70 refer to the amount of profits. Not surprisingly, the most common one (with 18 occurrences) is "big," but especially noticeable is the high frequency (16) and variety of words meaning "very big": basnoslovnyj (legendary, fabulous), ogromnyj (enormous), kolossal'nyj (colossal), etc. About two thirds of these are to be found in contexts where the means of making profit or the amount of profit is criticised, e.g.:

Unfortunately, some governments and companies immediately classified these [scientific] works as secret, hoping for large-scale advantages or enormous profits. (Ogonyok 2000)

This seems to be a remnant of the old, negatively connoted concept of profit. Another aspect of this concept is revealed in an article which states that very big profits can only be made in the West, but not in Russia:

You think the "Roverbook" notebooks earn the company legendary profits? In the West it could not be any other way: you crushed your competitors like the bear the aspen - now you can start the buying-up of villas on the Bahamas. But in Russia everything is the other way round. (Ogonyok 1997)

More often, however, authors in Ogonyok underline that extremely large profits are not the usual thing in the West, or in a stable market economy, but typical of the current economic situation in Russia.

In this year's ski season something like a full utilisation of the hotels happened for the first time. According to the mayor of Dombay [a Caucasian ski resort] the current profit rate in the hotels is 50 percent. This is much more than in civilised countries. (Ogonyok 1999) 
The West is - like in the Pietar interviews - often seen as a model for Russia. Russia must emulate the prosperous western countries in order to eventually become equally successful and "civilised." In a minority of cases, however, political commentators stress the uniqueness of Russia and the Russians and claim a different direction of development. "We are not like them [the 'West'] and they are different to us" - says one author, and characterises the Russians by "the collectivist component of our psychology, the unwillingness and inability of the greater part of the population to take part in the 'rat race' for profit." In such texts a principal difference between "the Russians" and "the Westerners" is built up, and Russia's belonging to the "West" is questioned. This is practically the only form of criticism of market economic principles in the texts from the Ogonyok magazine. It is tied to national differences, as opposed to the discourse in the Czech Republic, where the country's belonging to the "West" is beyond doubt, but single aspects of market economies, e.g. neoliberalist tendencies, can still be questioned. However, it must not be forgotten that this is a minority discourse in the studied Russian material. The dominating point of view in the Ogonyok magazine and in the Pietar interviews conceives of the capitalist countries as of the norm, or standard, that Russia must try to reach. A more differentiated view of market economy, neoliberalism or globalisation is unusual. A possible explanation for this might be the lack of experience with modern capitalism in Russian history even before 1917. Thus, the official socialist ideology could influence people's conceptualisation of profit in capitalism much more than in Czechoslovakia, where until 1948 the society's experiences had been very similar to those of other Central Europeans. Consequently, a widespread perception of a market economy in Russia seems to be that all formerly state-owned sectors can (or must) now be privatised and work for profit. This can even pertain to schools or hospitals. If an author criticises a non-profit organisation for making profit she has to legitimate and explain this criticism before her readers, even in the year of 2000:

Maybe there would be no need to report on the commercial activities of [the ophthalmic clinic] MNTK and its director, but the point is that Mr. Fedorov's clinic is nevertheless not an oil-processing plant. There are more and more people in Russia for whom eye surgery is vital. They cannot go to Fedorov's clinic, because the prices for treatments there rise every year [...]. Furthermore, as was already mentioned, MNTK is not a commercial enterprise, by definition it must not strive for profit. (Ogonyok 2000)

\section{Conclusion}

During the last 15 years the concept of profit, as reflected in Russian and Czech language use, has changed significantly. In the times of planned socialist economies a separate, positively evaluated notion of profit in socialism developed, as opposed to a negatively connoted concept of the profit made by 
capitalists. The Russian sources from the end of the 1980s illustrate how this dual concept was then gradually melded into a single new one and, at the same time, ascribed more and more importance.

In the second half of the 1990s the former differentiation is obsolete, profit is understood as a central factor in business and economics, and is generally evaluated positively. That means the concept of profit is now clearly that of a market economy, though some aspects of the traditional socialist concept can still be traced. Nevertheless, profit has become a key market economy concept for both the Russian and the Czech societies.

\section{References}

Bol’šaja sovetskaja ėnciklopedija. (1975): vol. 20, Moskva

Brokgauz, F.A./Efron, I.A. (1992 [1890]). Enciklopdičeskij slovar‘. Tom 49. Sankt-Peterburg

Kocek, J. et al. (2000): Český národní korpus. Úvod a př́ručka uživatele. Praha: Filozofická fakulta UK - Ústav Českého národního korpusu

Müller, B./Petters, J./Doleschal, U. (2002): Die Diffusion marktwirtschaftlicher Schlüsselkonzepte in Mittel- und Osteuropa: eine linguistische Analyse. Wien, Wirtschaftsuniversität, published via ePub:

Ožegov, S.I./Švedova/N.Ju. (1993): Tolkovyj slovar‘ russkogo jazyka. Moskva

Rathmayr, R. et al. (1999): „Pribyl’ - ulybka na lice“. Das semantische Spektrum ausgewählter russischer Wirtschaftstermini. In: Girke, W. et al. (eds.): Vertograd mnogocvetnyj. Festschrift für Helmut Jachnow. München: 229-240

Skljarevskaja, G.N. (ed.) (1998): Tolkovyj slovar‘ russkogo jazyka konca XX veka. Jazykovye izmenenija. Sankt-Peterburg

Stubbs, M. (1995): Collocations and semantic profiles. On the cause of the trouble with quantitative studies. - In: Functions of Language 2,1:23-55

Wierzbicka, A. (1997): Understanding Cultures Through Their Key Words. English, Russian, Polish, German and Japanese. New York, Oxford 